\title{
A expressão católica na Literatura Francesa e Brasileira do início do século $X X$
}

\author{
Cristina Francisca de Carvalho Porto*
}

\section{Resumo:}

Breve discussão sobre a formação do grupo de escritores católicos na França e no Brasil, na década de 20 e 30 . Esta discussão tem como principais tópicos: elencar alguns temas recorrentes na narrativa destes escritores; e, detectar algumas afinidades que vinculam estes romancistas, atentando sempre para a expressão religiosa de seus textos. Espera-se que tais reflexões permitam-nos compreender o surgimento de textos tão próximos em diferentes culturas.

\section{Palavras-chave:}

Literatura, França, Brasil, romance, religiosidade

\section{Introdução}

No início do século $X X$, o mundo era tomado por um sentimento de angústia gerado pelo pós-guerra (Primeira guerra mundial), era preciso reconstruir não apenas o material, mas, sobretudo, o espiritual. Nesta época, a maioria dos países se defrontou com um período de crises, cuja conseqüência foi o radicalismo e a violência. A literatura não podia ficar alheia a estes acontecimentos. Na França, um grupo de escritores guiado por Maurras e Jaques Maritain era cada vez mais lido, tendo seu apogeu no final da década de 20 e início da década de 30 . Por retratarem em seus textos as angústias e sofrimentos da época, a literatura produzida por eles foi designada "literatura do entre-guerras"; nela se inserem ainda François Mauriac, Georges Bernanos e Julien Green, todos católicos.

Muitos intelectuais brasileiros trouxeram da Europa, mais especificamente da França, além dessa literatura mais voltada para o sofrimento do ser, outros ideais revolucionários de movimentos que lá surgiam, um desses nomes foi Jackson Figueiredo, simpatizante da Action Française e católico fervoroso.

A união do nacionalismo com a ação católica era também objetivo do movimento francês, daí o interesse de Jackson, intelectual de espírito combativo e praticante de uma literatura revolucionária dirigida por um princípio: "a Arte, para ser realmente Arte, tem que ser moral, tem que ser católica" (MARTINS, 1979, p. 322). Com seu engajamento chamava a atenção de colegas lembrando que faltava à crítica literária uma doutrina social e consciente inspirada nos ensinamentos da Igreja. Ele arrebanhou para seu grupo vários nomes da literatura brasileira, entre eles Octávio de Faria, Lúcio Cardoso e Cornélio Penna, todos envolvidos com o catolicismo.

Motivada pela densidade dos temas que esses autores apresentavam iniciei a

* Departamento de Letras Modernas - Ibilce/Unesp, Doutora em Teoria Literária - UNESP. 
leitura de seus romances, dando origem assim à intenção de trabalhar com os mesmos, sobretudo Cornélio Penna e Julien Green, cujas obras apresentaram maior similaridade.

Um dos críticos que evidencia esta ligação entre os dois escritores é Tristão de Athayde, em seu comentário sobre Fronteira (1935). Nas notas preliminares aos romances completos de Cornélio Penna, o estudioso afirma:

Ora, justo na hora em que toda a atenção se voltava para o romance social, que parecia tão de acordo com o novo estado de espírito em que a Revolução de 30 colocara a nova geração - aparece o romance do Sr. Cornélio Penna. - E aparece com a coragem de sua perfeita inatualidade, como um verdadeiro desafio à moda dominante. E nisto está o primeiro dos seus méritos.

Foi, aliás, o que se passou em França com o romancista moderno, de cuja figura mais se aproxima o Sr. Cornélio Penna, a ponto de podermos chamá-lo o Julien Green brasileiro.

Pois bem, a impressão de grata surpresa que tive ao ler Le voyageur sur la terre que marcou, a meu ver, o fim do modernismo fogo de artifício em França - foi a mesma que tive lendo Fronteira. Neste livro também tudo é estranho e inatural. (ATHAYDE, 1958, p. 3-4)

Salientando o lugar de Julien Green e Cornélio Penna na produção literária no Brasil e na Europa e comparando suas obras, o crítico nos indica um dos primeiros elementos comuns entre os dois escritores: a ousadia em inovar não aderindo ao padrão literário da época.

Outro crítico também percebe ligações entre o autor francês e o brasileiro: tratase de Sérgio Milliet. Na nota preliminar a Repouso lemos:

Por certo deparamos em Adonias Filho, ou nos primeiros romances de Lúcio Cardoso com concepções análogas. Análogas mas não idênticas, porque ainda fazem ambos concessões à orientação nordestina, tanto no estilo como na técnica. Cornélio Penna esquece as lições do Nordeste, e vai procurar modelos fora do país, possivelmente em certas páginas de Kafka, ou de Julien Green, autores bem diferentes e que no entanto se conciliam no escritor brasileiro. (MILLIET, 1958, p. 379)

Milliet aponta o sentido inovador do estilo de Cornélio Penna e a busca de um novo campo temático, ainda inédito na literatura brasileira. Como Tristão de Athayde, o autor faz aproximações entre Cornélio Penna e escritores estrangeiros, entre eles Julien Green, sugerindo a possibilidade de o romancista brasileiro ter lido textos do escritor francês.

Ambos os críticos, de alguma maneira, ofereceram-nos sugestões no sentido de realizar um confronto entre a prosa introspectiva produzida nas décadas de 20 , 30 e 40, no Brasil, realizada ainda por Lúcio Cardoso e Octávio de Faria, e aquela efetuada na França por autores como François Mauriac, Georges Bernanos e, em especial, Julien Green.

Cornélio Penna, Octávio de Faria e Lúcio Cardoso, todos voltados para a problemá- 
tica existencial da personagem, incidiram particularmente sobre o lado tenebroso ou sobre as regiões interditadas da alma, com uma visão cristã marcada pelas concepções de Pascal e São João da Cruz a respeito da angústia, da humildade e do desespero humano.

Julien Green estreou em 1926, com Mont-Cinère; já nessa época, foi recebido pela crítica francesa como "herdeiro da mais terrível tradição 'gótica'", por abordar em seus romances histórias de pecados e crimes secretos, traço comum com Cornélio Penna, que recebeu de muitos críticos brasileiros a denominação de escritor "gótico", por realizar a mesma abordagem, sobretudo em Fronteira.

Outra particularidade do romance de Julien Green é a busca da libertação por meio da morte, coincidentemente a única saída encontrada pelas personagens cornelianas em sua busca pela liberdade. É, pois, em uma existência monótona de desejos insatisfeitos que seres greenianos desenvolvem uma vida subterrânea, fora do controle da consciência racional em que a comunicação só se realiza por meio do sonho e do inconsciente. Ao explorar o domínio do sonho, do campo onírico, Julien Green situa seus romances em um campo sobrenatural, como ocorreu também em Cornélio Penna.

Cornélio Penna marca uma reviravolta na ficção brasileira ao lançar, em 1935, seu primeiro romance, Fronteira, cuja abordagem principal é o tema do homem com seus problemas interiores, sua angústia, suas meditações sobre o destino, a morte e o além, realizando-se, portanto, uma temática alheia ao regionalismo em voga no período, cujos temas predominantes eram problemas sociais como a seca nordestina e a situação sócio-político-econômica dela decorrente.

O escritor não era explicitamente engajado em batalhas políticas, como católico praticante marcou seus escritos por profunda religiosidade e seu sentimento religioso chegou mesmo a ser associado ao fascismo que fermentava a década de 30, o que Ihe causou complicações e talvez tenha mesmo impedido maior repercussão de sua obra.

A possibilidade de um paralelo entre estes dois grupos de escritores, que a partir da leitura dos dois textos já se revelava viável, concretizou-se sobretudo após o contato com o texto de Teresinha Arco e Flexa (1990), cuja tese de doutorado também compara a obra de um escritor brasileiro, Lúcio Cardoso, a do escritor francês, Julien Green. Em sua pesquisa, ela já atentava para a temática espiritual.

A estudiosa salienta que em seu trabalho não interessa a "catolicidade" destes autores, mas sim, "verificar como tal temática se mostra resolvida ao nível estético: conflitos do indivíduo com Deus em suas várias manifestações, seja a aspiração à santidade ou o exercício quase ilógico da monstruosidade, na ausência de Deus" (ARCO E FLEXA, T., 1990, p. 21-22).

Para ela, dentre estes escritores, Cornélio Penna parece ser o mais singular com o seu mundo ficcional feito de inquietações, de atos ilógicos e de uma atmosfera atravessada pelas premonições.

Esperamos, após essa reflexão, chegar a alguns fatores que tenham possibilitado trabalhos tão semelhantes em culturas diferentes, como a do Brasil e a da França, 
e em uma época tão próxima.

2. Escritores católicos na França e no Brasil.

As obras de Cornélio Penna, escritor brasileiro, e de Julien Green, escritor francês, apresentam muitos pontos em comum, dentre os quais podemos destacar: o tema abordado, a base de inspiração para seus romances, além do envolvimento com o catolicismo comum a todo um grupo de escritores que se formou na mesma época no Brasil e na França e cujas marcas foram a introspecção, a reflexão e a sondagem do ser.

Para melhor entender a formação desses grupos e as idéias de seus integrantes, farei uma apresentação de seus representantes, bem como uma breve introdução sobre a expressão do catolicismo na literatura da época, sem, no entanto, debater sobre a questão específica da fundamentação da religião católica.

Um dos fatores comuns à formação dos grupos de escritores católicos na França e no Brasil é a reflexão sobre um determinado momento histórico, pois nos dois países ocorreram, no período do entre-guerras ${ }^{1}$, transformações sociais e políticas, assim como transformações de ordem moral.

A religião foi, para alguns, um refúgio ante a ruína dos valores morais após a primeira Guerra Mundial. O catolicismo conheceu, então, uma renovação que se traduz por um grande número de conversões em toda sociedade e isto ocorreu também no meio literário; daí o surgimento dos grupos de "escritores católicos". A adoção do catolicismo e o engajamento religioso levaram autores a transformarem suas inquietudes religiosas em temática literária.

\section{O catolicismo e seus representantes na literatura francesa}

$\mathrm{Na}$ França, o catolicismo ressurge com força singular na literatura por volta da década de vinte após a primeira Guerra Mundial. Nesse período, surgem vários escritores "católicos", que tinham como objetivo marcar suas obras pelo testemunho da convicção cristã.

O período do entre-guerras leva, assim, o meio literário a uma forte tendência à religiosidade, às vezes radical e sincera, outras superficial. Em meio a este "fulgor religioso" surgem as obras de Julien Green, François Mauriac e Georges Bernanos. Com a publicação de Sous le soleil de Satan, de Bernanos, em 1926, o debate sobre a literatura e a fé tem seu apogeu, dele participando escritores, filósofos, padres e leitores em geral.

Podemos dizer que a tendência religiosa-católica iniciou-se com duas importantes conversões: a de Paul Claudel em 1886 e a de Huysmans em 1893. Outras conversões importantes são as de Jacques e Raïssa Maritain em 1906, a de Charles Péguy em 1908 e a de Max Jacob em 1909, que se tornaram defensores de uma religiosidade considerada, por muitos, excessiva.

Julien Green, ainda jovem, deixa a Igreja Presbiteriana para juntar-se aos católicos durante a primeira Guerra Mundial e publica Mont-Cinère em 1926, Adrienne

${ }^{1}$ O termo "entre-guerras" refere-se, neste trabalho, ao período compreendido entre a primeira e a segunda guerras mundiais. 
Mesurat em 1927 e Léviathan em 1929. Ao grupo junta-se François Mauriac, com a publicação de Désert de l'amour em 1925, Thérèse Desqueyroux em 1927 e Le noeud de vipères em 1932, romance no qual a questão da graça aparece de maneira muito evidente. Não devemos deixar de incluir neste grupo André Gide, considerado, após o lançamento de Les Nourritures terrestres (1897), L'immoraliste (1902), La porte étroite (1909) e Les faux-monnayeurs (1925), um mestre por sua geração. Gide é um escritor ambíguo no que concerne à religião. Como Green, também era de origem protestante, converte-se na fase adulta ao catolicismo sem, no entanto, engajar-se como os demais escritores.

Outro escritor ambíguo mas representativo entre os católicos foi Charles Maurras, fundador do movimento "Action Française" e do jornal com o mesmo nome, cujo pensamento era essencialmente anti-republicano, baseado no ideal da restauração monárquica. Esse intelectual parece ter exercido uma considerável influência intelectual e política no início do século XX. Ele fundamentava suas concepções políticas sobre dois princípios: o nacionalismo e o socialismo, a pátria vindo antes de tudo. Apesar de ter sido o chefe de um dos mais ardorosos movimentos apoiados pelos católicos no século $X X$, ele se manteve incrédulo até a morte.

O movimento "Action Française" nasceu em 20 de junho de 1899, o documento de lançamento incluía quatro pontos fundamentais, dentre os quais se destaca o segundo:

De todas as formas sociais comuns no gênero humano, a única completa, a mais sólida e a mais vasta, é evidentemente a nacionalidade. Desde que se viu dissolvida a antiga associação conhecida como Cristandade e que dava continuidade, em alguns aspectos, à unidade do mundo romano, a nacionalidade constitui a condição rigorosa, absoluta, de toda humanidade. O nacionalismo não é portanto uma questão apenas de sentimento: é uma obrigação racional e matemática. (CHIRON, La vie de Maurras. In: FEDELI, p. 16, Tradução nossa)

O nacionalismo radical do movimento exigia que seus membros se comprometessem a defender a monarquia francesa de todos os meios possíveis e o fato desse movimento ter conquistado a simpatia de muitos católicos explica-se, em parte, nesta declaração de Maurras:

Todas nossas idéias favoritas, ordem, tradição, disciplina, hierarquia, autoridade, continuidade, unidade, trabalho, família, corporação, descentralização, autonomia, organização operária, foram conservadas e aperfeiçoadas pelo catolicismo. Como o catolicismo da Idade-Média se compôs na filosofia de Aristóteles, nosso naturalismo social tomava do catolicismo um de seus pontos de apoio mais sólidos e mais queridos. Vejamos a importante distinção: as idéias foram conservadas e aperfeiçoadas pelo catolicismo, elas não se originaram dele. (JF, In: FEDELI, p. 20, Tradução nossa)

A "Action Française" também defendia a Igreja das perseguições democráticas promovidas pelo governo maçônico e republicano da França; por estas idéias, 
Maurras é defendido com ardor por muitos católicos que o consideram um belo defensor da fé, apesar de seu passado pagão e agnóstico.

Maurras via no cristianismo apenas um valor humano e naturalista, e o valor do catolicismo era considerado em sua coincidência com o bem da nação francesa. $\mathrm{Na}$ França, o catolicismo foi um dos componentes da identidade nacional, nesse sentido é que Maurras se coloca como defensor da Igreja e não por fé religiosa. Os anos vinte marcaram, na França, a espera por uma obra literária católica de qualidade. O meio intelectual exigente e comprometido com a questão religiosa, bem como seu público, anseiam por uma produção eficientemente católica: daí o sucesso da obra de Bernanos, Sous le soleil de Satan (1926).

Bernanos satisfaz assim os críticos literários sensíveis às questões espirituais. Seu primeiro romance é aclamado igualmente por críticos hostis ou indiferentes ao catolicismo, e sobretudo pelos leitores. Sem ilustrar nem defender uma causa católica, ele descreve uma vida cristã em toda sua profundeza, evidenciando até suas contradições. $\mathrm{O}$ autor, que recusa a etiqueta de escritor católico por preferir a de católico escritor, declara que sua primeira produção é um dos livros nascidos da guerra. Trata-se, sem dúvida, do primeiro a evocar uma outra guerra: a luta pela santidade.

No decorrer dos anos trinta, os escritores católicos continuam a ter importância no conjunto da produção literária francesa. Mauriac, Claudel e Bernanos mantêm um grande número de leitores. Após a segunda Guerra Mundial a influência católica na literatura começa a diminuir, mas não desaparece, havendo sempre um retorno do espiritual do pensamento religioso nas artes em geral.

François Mauriac, novelista, ensaísta, poeta e jornalista, recebeu o prêmio Nobel de literatura em 1952. Suas novelas um tanto sombrias, constituem dramas psicológicos e analisam aspectos da vida moderna, com personagens que lutam com dilemas como o pecado, a graça e a salvação.

Mauriac pertenceu a uma família católica de classe média, daí herdando o gosto pelo catolicismo. Seus primeiros romances publicados foram L'Enfant chargé de chaînes (1913), e La Robe prétexte (1914). Após um período de interrupção devido à guerra, ele se afirmará como romancista com as obras La Chair et le Sang (1920), e Préséances (1921), momento em que tem início um período de intensa produção literária e Mauriac escreve alguns de seus melhores romances, como Thérèse Desqueyroux (1927). Em 1932, surge Le Noeud de vipères, considerado por muitos críticos sua obra-prima, trata-se de um drama que narra o ódio de um velho advogado contra sua família, sua paixão por dinheiro e sua conversão final. Nessa obra, como em outras de Mauriac, as personagens buscam, em vão, o amor nas relações humanas, amor este que somente será encontrado na relação com Deus.

François Mauriac foi um escritor polêmico: protestou contra o totalitarismo e denunciou o fascismo na Itália e na Espanha, também trabalhou com os escritores da Résistance durante a segunda Guerra Mundial.

Outro escritor que pertencia a este grupo de escritores franceses guiados pela fé católica foi Julien Green. Educado pela mãe na fé evangélica, Julien Green 
converteu-se ao catolicismo aos 15 anos após ler um livro escrito por um jesuíta francês sobre a fé católica e outro do Cardeal de Baltimore que respondia a todas as suas inquietudes. O próprio Green narra o momento de sua conversão com as seguintes palavras:

Pareceu-me, então, que, morrendo de sede, uma água fresca me fora vertida de uma fonte inesgotável, uma água deliciosa que espadanava alegria. O que eu desejava saber, sabia-o enfim, o que desejava crer fora-me dado em profusão. Essa água mais embriagadora que o vinho me transformou de súbito e me tornei católico de vontade, sem hesitação alguma, num imenso ímpeto para Deus. (GREEN, In: O itinerário religioso de Julien Green. Silveira, Alcântara. Supl. Cultura. O estado de S. Paulo. 12/08/84, p. 9)

Julien Green iria considerar, mais tarde, o ano de 1916 como o tempo mais feliz de sua vida. Essa felicidade, no entanto, não perdurou, porque sua fé não tinha ainda raízes profundas e a cruz lhe parecia por demais pesada. Os primeiros diários de Green refletem seu terrível estado de espírito nessa época, suas hesitações entre os prazeres do mundo e os sacrifícios da religião.

Green não se conformava com o comportamento dos freqüentadores da Igreja Católica que, segundo ele, não viviam o catolicismo como era devido, e a fé começou a abandoná-lo. Para manifestar seu descontentamento ele resolveu publicar um Pamphlet contre les catholiques de France, sob o pseudônimo de Théophile Delaporte. Esse panfleto foi a expressão daquilo que o autor pedia aos católicos; escrito no leito, por motivos de doença, suas páginas denunciam o conformismo da carolice francesa:

'Afinal, o que você acha o mais interessante de tudo? - A religião!' Esta palavra que vinha das profundezas do meu ser, eu a digo com uma voz que a emoção abafava um pouco. 'Você é católico? - Católico romano.' Eu estava tão orgulhoso por sê-lo que este fato impunha uma distância considerável entre mim e aqueles que não gozavam do mesmo privilégio. Meu companheiro, que era perspicaz, queria saber se eu estava totalmente de acordo com os católicos de minha época. Foi como se ele me tivesse dado meu livro inteiramente escrito, da primeira à última linha. (GREEN, 1982, p. 17-18, Tradução nossa)

Nestas palavras, Green nos confidencia o nascimento de seu panfleto. Como ele, outros escritores também deram o testemunho sobre seu surgimento no meio literário.

Maritain analisou as condições em que apareceu o panfleto, exprimindo sua admiração de escritor pela "dureza desses belos contornos pascalinos", expressou a alegria que pressentia no autor da obra - "uma alma excepcionalmente profunda".

O filósofo não se enganou pois os textos escritos por Julien Green durante sua crise religiosa revelaram o aparecimento de um grande romancista. "Coragem, Green! Sua obra é boa", escrevia Bernanos ao saudar o aparecimento de MontCinère em 1926. A esse romance, seguiram-se Le voyageur sur la terre, Adrien- 
ne Mesurat, Léviathan, L'autre sommeil, Épaves, Le visionnaire, entre outros, cada qual revelando uma faceta da angústia, da reflexão e das assombrações que rodeavam o autor.

Seres que vivem entre a loucura e a lucidez, assim podem ser classificadas as personagens de Julien Green.

É na religião, e em conseqüência dela, que Green passará os momentos mais conturbados de sua vida. Um acontecimento triste foi o da morte da mãe, era ela quem com ele rezava todas as noites incentivando a contemplação religiosa, como ele mesmo narra:

... quando ia deitar-me, minha mãe se aproximava para fazer-me rezar. Nós nos colocávamos de joelhos, eu no leito, ela sobre o assoalho e bem próxima de mim, a ponto de nossos rostos se tocarem; eu passava, então, os braços em torno de seu pescoço e repetia, após ela, as palavras da oração dominical, como se encontra na versão inglesa do Novo Testamento. [...] Com a cabeça sobre seus ombros, eu sentia grande prazer em repetir as palavras, cujo sentido me parecia obscuro, mas cuja doçura atingia as mais misteriosas regiões da alma. Parecia-me, quando eu tinha os braços em torno do pescoço da minha mãe e rezava com ela, que nada no mundo poderia aborrecer-nos. (SILVEIRA, 1984)

Assim, nascia na cumplicidade com a mãe a construção da fé e desenvolvia-se nele o gosto pela religião. A partir da morte da mãe desencadearam-se suas dúvidas e angústias em relação à sua religiosidade.

Para Barcellos (2001, p 82) é impossível falar de Green e de sua obra sem nos referirmos ao problema da identidade. O crítico lembra que vida e obra são um longo percurso de busca, construção e reconstrução de identidade lingüística, nacional, religiosa, sexual e literária; busca de si, encontro com o outro, encontro de si, busca do outro.

4. O catolicismo e seus representantes na literatura brasileira

Em 1921 tem início no Brasil um período de harmonia entre Igreja e Estado, de aprofundamento do pensar religioso pelos princípios da doutrina católica.

Nesse período houve uma retomada da busca religiosa, surgiram novos centros de estudos teológicos e filosóficos, evidenciados pelo interesse dos leigos no aprofundamento da sua fé. Surgem as Universidades Católicas e difundem-se os colégios católicos, formando alunos responsáveis pela difusão do pensamento da igreja em suas futuras profissões.

Assim como na França, podemos dizer que o recrudescimento do pensamento católico começa a atingir seu apogeu aqui no Brasil. Por outro lado, no início do século XX, havia movimentos políticos mal vistos pela Igreja, entre eles a Action Française, por sugerirem um novo sistema religioso, moral e social. Esses movimentos tiveram repercussão também no Brasil, onde Jackson de Figueiredo tornou-se representante dos ideais da Action Française.

Às idéias tomadas à Action Française filiaram-se, no Brasil movimentos como a Aliança Nacional Libertadora, e, em 1932, a Ação Integralista Brasileira. Os ca- 
tólicos, de modo geral, e, dentre eles vários intelectuais, posicionaram-se contra o comunismo, mas mostraram-se simpatizantes do integralismo.

A atração exercida pelo integralismo deveu-se a sua posição espiritualista, bem como à valorização das tradições cristãs e ao combate ao comunismo. Entretanto, esse movimento não tardou a ser visto como um perigo para o catolicismo. Muito envolvente, dada a constância dos rituais semelhantes à ritualística religiosa, poderia, portanto, tornar-se um substituto para a religião e angariar a dedicação que os fiéis deveriam ter com a Ação Católica.

Na década de 30, difundiram-se também no Brasil as idéias filosóficas de Jacques Maritain, crítico e pensador cristão de grande atuação na França. Sua visão trouxe grandes contribuições para o pensamento católico e despertou o interesse dos intelectuais brasileiros católicos e não-católicos pelas transcendentes questões da metafísica tomista.

A difusão do catolicismo no Brasil nos anos 30, no entanto, não é facilmente justificável, suas raízes, aqui, vêm de diversas fontes e não podemos, portanto, afirmar que a influência francesa tenha sido a mais forte entre nossos escritores dessa época. Mário de Andrade, ao referir-se ao catolicismo, expõe suas dúvidas e tristezas em relação à maneira como os brasileiros o praticam:

O problema da catolicidade brasileira é dos mais delicados da entidade nacional e, por mim, jamais cheguei a uma verdade nítida. Confesso que não consigo verificar bem na gente brasileira um catolicismo essencial, digno do nome de religião. Principalmente como fenômeno social. Digo isso com tristeza porque me parece mais outra miséria nossa, porém o que tenho percebido em nós é uma tradição ou costume católico, vindo de fora pra dentro, na infinita maioria dos eruditos e semi-eruditos, muito deturpado pelo carinho sentimental às memórias de infância e tradição. Nada ou quase nada essencial. Por meio desse costume que tem quatro séculos de raízes, era natural que existisse em nós uma espontaneidade católica. Ela existe. Mas reage a infinita maioria das vezes como fenômeno individualista: não funde mais a gente em movimentos de ataque ou de defesa coletiva. (ANDRADE, 1972, p. 13)

Esse catolicismo de "costume" a que faz referência Mário de Andrade será criticado também pelos vários escritores que citaremos a seguir. Apesar de admitirem ter recebido o catolicismo como herança de seus pais, eles demonstraram, em seus textos, uma aversão àqueles que o praticavam apenas como hábito, sem realmente engajar-se na causa Católica.

Um escritor católico de grande influência intelectual na década de 30 foi Jackson de Figueiredo. Nascido em Aracaju, herdou de sua mãe a fé católica, mas somente aos 27 anos converteu-se ao catolicismo. Podemos conhecer melhor o perfil deste jovem pensador por um dos trechos da carta de seu amigo Farias Brito:

Como Pascal, filósofo torturado pela nostalgia do infinito, é com estes dois grandes espíritos (Pascal e Novalis) que o acho parecido, sobretudo com Pascal, considerando a complexidade extrema do seu espírito assim, feito para a independência e para a divindade, 
certamente afinidades profundas: fato este de que experimentamos o sentimento vivo e palpitante.

E foi talvez isto o que, desde logo, tão profundamente nos uniu. (MOURA, 1978, p. 148)

Farias Brito traça não apenas o retrato psicológico de Jackson, como também, as linhas principais de sua trajetória intelectual. Seus livros de temas filosóficos não podem ser considerados representativos do pensamento cristão, mas são testemunhos de sua evolução para o catolicismo: Algumas reflexões sobre a filosofia de Farias Brito (1919) e Pascal e a Inquietação Moderna (1922).

Por ser seu ideal "catolicizar a inteligência brasileira", Jackson foi considerado um apóstolo dos intelectuais. Ele foi literato, poeta e jornalista; não é possível considerá-lo um filósofo católico, mas seu pensamento foi de grande importância para o grupo de escritores engajados ao catolicismo, devido às lutas que abraçou em defesa da Igreja e da política governamental.

Alceu Amoroso Lima discordava das idéias de Jackson, pois, enquanto este era simpatizante de Maurras, chefe da "Action Française", Alceu preferia a linha libertária de Maritain. Em comum com Jackson ele terá somente o traço de apóstolo da inteligência católica.

Alceu iniciou sua crítica literária em 1919, escrevendo em O Jornal, com o pseudônimo de Tristão de Ataíde, mas, após sua conversão ao catolicismo, praticamente abandonou a crítica literária e guiou-se em sua produção sobretudo pelas linhas ideológicas de Jacques Maritain.

Ainda sobre sua contribuição para os intelectuais católicos Mário de Andrade acrescenta:

Tristão de Ataíde é talvez o exemplo mais útil que se possa apresentar à mocidade brasileira, covarde e indecisa. Não apenas aos católicos, mas a todos em geral, que, na ordem das usas crenças e destinos desejados, teem a copiar dele o desassombro, a cultura coordenada, a nobreza de intenção, o incorruptível do caráter. (ANDRADE, 1972, p. 7)

O crítico deixa evidente sua admiração pelo caráter de Alceu Amoroso Lima (designado por seu pseudônimo), mas também lamenta o fato de sua conversão ao catolicismo tê-lo distanciado da crítica literária: "... Perdemos um excelente crítico literário, apesar dos defeitos, excelente; ganhamos um pensador católico. (Ibid., p. 10)"

Neste grupo de escritores católicos, também merece destaque Octávio de Faria. Nascido no Rio de Janeiro, foi crítico, ensaísta, romancista e tradutor. Apesar de sua personalidade introspectiva, ele se impôs como líder desde a época de estudante, tomando parte em vários trabalhos culturais e jurídicos. Bacharel em Direito, nunca exerceu a profissão, dedicando-se somente à literatura. Em 1927 inicia suas atividades literárias colaborando em A Ordem, órgão do Centro D. Vital, bem como em diversas outras revistas literárias e políticas.

O ensaísta de Maquiavel e o Brasil (1931), Destino do socialismo (1933) e Dois poetas (1935), logo cede lugar ao romancista, em cujo estilo predominam a aná- 
lise das idéias e dos acontecimentos sociais. Em 1937, Octávio de Faria publica seu primeiro romance, intitulado Mundos mortos, ponto de partida para o grande projeto literário $A$ tragédia burguesa. Dos vinte volumes projetados, apenas treze foram publicados. O escritor apresenta, na Tragédia burguesa, um painel da vida carioca, mesclando os problemas sociais do processo de formação da burguesia aos grandes problemas do homem. Trata-se de uma obra que se destaca pela continuidade, exploração psicológica dos tipos e entrosamento familiar, comparável apenas à Comédia humana de Balzac.

Outro escritor de destaque neste grupo foi Lúcio Cardoso, este inicia sua carreira com a publicação de Maleita, apenas possível devido às suas relações com Augusto Frederico Schmidt, que se lançava como editor. Nesse primeiro romance revela-se o pendor do autor para a criação de atmosferas de pesadelo mas, com a publicação, em 1936, de A Luz no Subsolo, o escritor define-se pelo romance de sondagem interior.

Lúcio manteve-se até à morte ligado a alguns escritores que, na década de 30, eram denominados "espiritualistas e católicos", entre eles Otávio de Faria e Cornélio Penna, sendo o último o que dele mais se aproxima, como podemos constatar nas palavras de Bosi:

Lúcio Cardoso e Cornélio Penna foram talvez os únicos narradores brasileiros da década de 30 capazes de aproveitar sugestões do surrealismo sem perder de vista a paisagem moral da província que entra como clima nos seus romances. A decadência das velhas fazendas e a modorra dos burgos interioranos compõem atmosferas imóveis e pesadas onde se moverão aquelas suas criaturas insólitas, oprimidas por angústias e fixações que o destino afinal consumará em atos imediatamente gratuitos, mas necessários dentro da lógica poética da trama. O leitor estranha, à primeira leitura, certa imotivação na conduta das personagens. É que os vínculos rotineiros de causa e efeito estão afrouxados nesse tipo de narrativa, já distante do mero relato psicológico. Lúcio Cardoso não é um memorialista, mas um inventor de totalidades existenciais. Não faz elencos de atitudes ilhadas: postula estados globais, religiosos, de graça e de pecado. (BOSI, 1972, p. 414)

Bosi sintetiza aqui o estilo de Lúcio Cardoso, apontando a característica das obras. Em seguida, o crítico ressalta a superação do romancista ao dedicar-se a reconstrução de um clima de morbidez envolvendo os ambientes e os seres. A Crônica da Casa Assassinada, de 1959, revela as angústias de um amor que se crê incestuoso; nesse romance, cuja estrutura é semelhante a de Le voyageur sur la terre, de Julien Green, nos deparamos com cartas, diários e confissões das pessoas que conheceram a protagonista. A coexistência destas formas de escrita caracterizam ambos os livros.

Segundo Bosi, ao redigir a Crônica da Casa Assassinada, Lúcio caminhava para uma forma complexa de romance em que o introspectivo, o atmosférico e o sensorial não mais se justapõem mas se combinam como uma escritura cerrada, capaz de converter o descritivo em onírico e adensar o psicológico no existencial. Vejamos agora Cornélio Penna, cuja identidade literária vem de sua infância, pois 
daí nasce a principal marca de suas obras; são as informações recebidas durante este período que, além de moldar sua personalidade, darão forma a seu estilo. Cornélio Penna usará a cidade de seus avós, onde passou parte da infância, como cenário para seus enredos. A esse cenário unem-se fatos reais acontecidos na época em que se passa a história, como a Revolução da Armada, e, ainda o clima de mistério sugerido pelas cidades mineiras, o que fortalece o clima gótico de sua obra.

Os que se deparam com a obra de Cornélio Penna, sempre questionam esse total desconhecimento em relação ao escritor. Apesar de seu estilo renovador e audacioso, trata-se de um autor pouco lido, e, praticamente, esquecido na atualidade. A crítica, de modo geral, coloca algumas razões para tal esquecimento, por exemplo, eles apontam como principal razão do desprestígio literário de Cornélio Penna o fato de o escritor ter feito sua estréia literária na década de trinta, época de domínio do romance social de corte regionalista. E, também, ser identificado como católico, quando nos meios intelectuais brasileiros, não era rara a confusão entre "catolicismo" e "carolismo", talvez tenha agravado ainda mais a situação de Cornélio Penna. Nesse sentido, convém recordar que a década de 30 foi um período político conturbado.

Cornélio Penna, nessa época, tinha amizade com um grupo de escritores formado por Tristão de Athayde, Lúcio Cardoso e Octávio de Faria que não era bem visto politicamente, devido a ligação com o Integralismo, muito identificado com o fascismo. Talvez isso tenha dificultado a ascensão de Cornélio Penna enquanto escritor, conforme podemos constatar abaixo:

Roberto Schwarz apontou certa vez que, nos anos 60, a despeito de estarmos numa ditadura de direita, o pensamento de esquerda dominou a intelectualidade brasileira. Coincidiu com esse período o início do esquecimento da obra de Cornélio Penna: ainda em 1958 ela era considerada suficientemente relevante para merecer uma edição integral pela Aguilar. É certo que contribuiu muito para esse esquecimento o fato de o autor de Fronteira ter sido católico e próximo a artistas de ligação histórica com o pensamento político mais reacionário (bastaria lembrar o Otávio de Faria dos anos 30 e 40). (BUENO, 1998, p. 6)

Outro crítico a discutir esta questão do envolvimento político de Cornélio Penna, porém sob uma perspectiva mais estrutural do que poética, é Adonias Filho. Para ele, a "linguagem" tem uma posição dominante na obra e à sombra dela fundemse ficcionista e escritor que se completam na sua homogeneidade. Para o crítico, outro fator de extrema importância é a "mensagem" do romancista:

Pode-se assegurar que, em obra novelística como a de Cornélio Penna, não será difícil o reconhecimento crítico da mensagem. Inteiriça, como acabamos de verificar, - no processo técnico de construção, na problemática especulativa, na linguagem como um elemento clássico, - projeta-se na mensagem como em um campo aberto. Na mensagem, e porque estabelece as relações entre a obra novelística, seu momento histórico e a literatura brasileira, é que se deve buscar a própria significação dos romances. (ADONIAS FILHO, 1958, 
p. 15-16)

A essas palavras seguem-se seis capítulos, sendo o primeiro sobre o envolvimento, em termos político e social, do escritor com sua época, ressaltando sua participação ativa na História. Cornélio Penna fez parte de uma geração revolucionária, herdeira das conseqüências da primeira guerra mundial e que se dividiu em três círculos: político, militar e intelectual, tendo como objetivo comum a reforma nacional. Apesar de se abrir em aspectos distintos, trata-se de um único movimento, cujo traço é o nativismo. Os círculos político e militar serão os responsáveis pela série de movimentos armados que se iniciam em 1922 e atingem seu auge com a revolução de 1930. No círculo intelectual, haverá a "revolução modernista" que prosseguiu até 1930 .

Após a vitória das duas revoluções, em 1930, inicia-se o que Adonias Filho designa "a fase construtiva" da arte: "É a partir desse ano, ao lado da reforma da organização política, que as conseqüências modernistas se convertem em experiências literárias e plásticas assegurando nova configuração à poesia, à ficção em prosa, à arquitetura, à escultura, e à pintura" (Ibid., p.19).

Cornélio Penna participa das duas fases, a anterior e a posterior a 1930, atuando plenamente e servindo-se de seu trabalho para condenar o conformismo das gerações anteriores.

O crítico aponta, ainda, um fator que justifique, talvez, a importância de Cornélio Penna para a literatura brasileira. Ele salienta que, enquanto todos os seus companheiros de geração literária ampliavam o documentário (sobretudo no círculo nordestino) e o realismo psicológico (sobretudo no círculo sulista), Cornélio Penna seguia por um caminho diferente: "É a partir de Fronteira que a renovação se inicia. O romancista, desprezando a revolução lingüística - e na linguagem estabelecendo o contato com o romance superado - ingressa no território temático para enriquecê-lo com um novo afluente" (Ibid., p. 21).

O mesmo ocorre na França com Julien Green que rompe com o modismo literário da época e adentra no que a crítica literária francesa designou pré-existencialismo.

Além do rompimento com os estilos dominantes, Cornélio Penna e Julien Green buscam inspiração em lembranças da infância. Ambos encontram na memória do passado temas ou ambientes para a composição de seus romances.

Bueno afirma que as personagens cornelianas vivem à exaustão um clima intenso de pecado, são seres que se encontram numa margem indefinida entre a loucura e a lucidez. Esta seria a substância de Fronteira - a vida de Maria Santa morta às vésperas de revelar ao mundo sua santidade: "Isolada em um casarão mineiro de Itabira, sem contato com o movimento de vida da pequena cidade, Maria Santa consome a si mesma e a sua santidade, por não dar a ela real existência" (BUENO, 1996, p. 5).

Cornélio Penna ingressa na Literatura Brasileira apresentando ao mundo sua estranha personagem que, apesar de solitária em sua história, não está só no seu drama existencial. Aí também se inserem várias outras personagens das obras 
tanto de Penna quanto de Green.

Ao repassarem, ambos, por meio da narrativa, a experiência que trouxeram do passado, a memória que buscaram no fundo de suas lembranças da infância, resgatam também histórias de vários povos, da sociedade a que pertenceram suas famílias. Reavivando tantos fatos, mantiveram acesa a cultura de uma nação, por meio da obra desses autores aspectos da identidade de grupos diferentes foram resgatados na literatura.

Relatando suas memórias, esses escritores não o fizeram apenas por profissão, mas sobretudo por doação, quase como uma necessidade de revelar ao próximo suas experiências. Julien Green bem define:

Eu estou na terra por uma razão que só posso entrever. O senhor conhece essa palavra maravilhosa de D'Annunzio: 'Eu tenho o que eu dei?'Eu diria, quanto a mim, que dou o que recebi, ou pelo menos eu tento. Alguma coisa me foi dada e me é muito difícil resistir ao desejo de traduzir em palavras o que me foi dado. Não posso não escrever. (Julien Green) (BARCELLOS, 2001, p. 81)

Mais do que uma profissão, escrever significava, portanto, a possibilidade de desabafar, de divulgar as informações recebidas. Também para Cornélio Penna, se lembrarmos as várias declarações de suas entrevistas, o ato de escrever era um desabafo, uma necessidade constante e muito forte.

Talvez isto ocorra por terem vivido ambos em períodos historicamente conturbados, em que o mundo todo se deparava com inúmeras revoltas, sobretudo, as duas grandes guerras mundiais. As guerras não deixam apenas marcas físicas, mas também mentais, das quais as mais profundas ficam na alma daqueles que, de alguma forma, presenciaram os acontecimentos.

Cornélio Penna e Julien Green dividem, além da angústia deixada pelas guerras, as dúvidas implantadas pela religião, a busca da fé e a busca por Deus.

A busca constante por Deus é uma forte marca não apenas nos dois escritores como também em suas personagens. Assim como essa busca, o resgate da infância, do fato histórico, das histórias contadas por seus familiares são elementos que podem ser encontrados nas obras destes escritores.

\section{Conclusão}

Aliado à tensão política temos também o Modernismo, com suas questões inovadoras, seu projeto de modernização da linguagem e idéias vanguardistas; era preciso, portanto, que os mais tradicionais se unissem contra um projeto que poderia colocar em risco a moral cristã.

Há, no entanto, quem veja nestes romances de 30 uma continuação do projeto Modernista. Segundo Bueno (2006, p. 56) a literatura de 30 é vista como um alargamento do espírito de 22, indicando a presença de um momento a partir do qual algo de mais consistente pudesse ter lugar, mostrando que o que nega e o que afirma acabam se encontrando. Isso é denominado pelo crítico "manifestação de um espírito de época", e segundo ele, levar em conta esse espírito de época 
é admitir que, para a intelectualidade de 30, há uma tensão forte entre dois momentos: o modernismo e o pós-modernismo.

Bueno acrescenta que a sustentação da proposição segundo a qual as transformações sofridas pela forma de fazer literatura no Brasil entre os decênios de $20 \mathrm{e}$ 30 não constitui dois momentos diferentes, mas duas fases de um só momento a se diferenciarem por uma ênfase maior no projeto estético ou no ideológico, depende da compreensão da existência de um mesmo projeto estético e um mesmo projeto ideológico. Para ele é inegável que a geração dos autores que participaram da Semana de Arte Moderna preocupava-se sobretudo com uma revolução estética, enquanto os que estrearam nos anos 30 centravam sua atenção nas questões ideológicas. Assim, segundo ele, não é fácil admitir uma continuidade dos projetos estético e ideológico de uma geração para outra de forma que a ênfase num ou noutro abarque os desacordos que separam essas gerações.

Essa movimentação artística entretanto não elevou o mérito do Brasil diante dos países desenvolvidos, conforme aponta o crítico:

Se a distância que nos separa dos países ricos não se modificou, a mudança de perspectiva sobre o país corresponde a um deslocamento no plano ideológico: mudou a visão de Brasil. [...] Essa diferença de visão dominante do país é elemento central nas diferentes formas de ação privilegiadas pelos modernistas e pelos romancistas de 30. Ora, a idéia de país novo, a ser construído, é plenamente compatível com o tipo de utopia que um projeto de vanguarda artística sempre pressupõe: ambos pensam o presente como ponto de onde se projeta o futuro. Uma consciência nascente de subdesenvolvimento, por sua vez, adia a utopia e mergulha na incompletude do presente, esquadrinhando-o, o que é compatível com o espírito que orientou os romancistas de 30. (BUENO, 2006, p. 59)

Com tal colocação ele amplia a formulação de João Luiz Lafetá de o romance de 30 ser o momento da "literatura na revolução" e o modernismo de 22 o da "revolução na literatura"; o que ambos desejam mostrar é o fato desse pequeno deslocamento de sentido poder ser visto como demonstração de um afastamento dos projetos de cada geração e não de uma aproximação entre eles.

0 estudo de Bueno revela-nos também que o romance de 30 nasceu realmente da fermentação revolucionária da década; acrescentamos ainda que se deve a essas revoluções a busca de alguns escritores pelo catolicismo, mas do catolicismo tomado aos escritores franceses como Mauriac e Bernanos, em cuja obra inscreviam-se os sofrimentos da guerra, a crise do mito do progresso assim como a formação intelectual e moral dada pela educação católica.

As guerras e as revoluções deixavam no homem da época um total sentimento de abandono, a sensação de estar só em meio à multidão, daí o sentimento de desamparo; era preciso, portanto buscar refúgio e muitos encontraram na religião católica este amparo.

O rigor da religião vai ressoar na literatura de diversas maneiras, uma delas Bueno nos mostra na obra de Octávio de Faria: 
De toda maneira, é certamente essa luta do homem contra as forças da imoralidade, do seu próprio instinto sexual, que atraiu a atenção de Octávio de Faria em Sob o Olhar Malicioso dos Trópicos. Anos antes do inquérito ele já havia se referido elogiosamente ao romance em artigos, como o célebre "Excesso de Norte" ou numa resenha de Salgueiro, de Lúcio Cardoso. Mas o interesse do livro, quando posto em confronto com a produção dos anos 30, não reside aí, onde Octávio de Faria o encontrou. Está muito mais no método narrativo, introspectivo até à medula, que ressoará indiretamente em obras posteriores, como as de um Cornélio Penna, por exemplo, ajudando a estabelecer um certo padrão de romance psicológico que terá grande desenvolvimento no período. (BUENO, 2006, p. 99)

Ao lado de Octávio de Faria e Lúcio Cardoso, Cornélio Penna desenvolve seu romance que, além da forte marca da introspecção e do psicológico, trará ainda as marcas do engajamento religioso do autor, que o conduzirá para um lado paralelo ao de seu colega católico, Jackson de Figueiredo: enquanto este misturou a questão espiritual com a política, Penna construiu sua produção literária mais voltada para a evangelização.

Todo esse processo que até então delineamos foi parecido ao ocorrido na Europa, e por que não afirmar, importado, principalmente da França. Assim poder-se-ia compreender o aparecimento de produções tão próximas nos dois países, bem como a constituição dos grupos de escritores católicos.

O fator histórico, englobando guerras, e a religião católica, são a primeira marca comum recebida por estes escritores. Por terem a mesma religião e terem sofrido os mesmos dilemas, iniciaram sua produção literária desenvolvendo os mesmos temas, o mesmo clima, os mesmos dramas. No caso do Brasil, não podemos negar que algumas influências tenham vindo também de leituras importadas da França, pois neste período era comum homens de posse fazerem seus estudos na Europa e, ao retornarem, trazerem para nosso país as idéias lá difundidas.

Porém, apesar da proximidade não podemos negar que cada escritor atribuiu a sua produção um elemento nacional, imbuindo seu trabalho de algum elemento individual que o distinguirá dos demais.

Assim, ainda que todos esses escritores católicos, brasileiros e franceses, escrevessem sobre um mesmo tema e revelassem em suas obras sua religiosidade e seu catolicismo, eles focaram indivíduos diferentes, concretizados na figura das personagens, possibilitando uma distinção em relação ao fator enfatizado. Se em Green o foco está na fé, no falso cristão, em Mauriac está no pecado, na tentação; em Bernanos, naquele que tentava: o próprio Satã; e, em Penna, na reconciliação com Deus.

A religiosidade desses escritores aponta para uma produção que responde a preocupações metafísicas destoando assim de obras do mesmo período voltadas para o social, a política e os manifestos modernistas; seus textos realizam um retorno à tradição da vertente religiosa. O misticismo da espiritualidade dos romances católicos produz imagens de um sobrenatural ilusório, sem lógica, apropriado ao universo angustiante das narrativas.

Essas obras colaboram, não como instrumento didático ditando procedimentos 
éticos, mas como instrumento de reflexão a respeito de questionamentos e dúvidas sobre a nossa existência, sobre política e religião, inquietações, portanto, comuns a todos os seres humanos.

\section{Bibliografia:}

ADONIAS, Filho. Os romances de Lúcio Cardoso. In: Modernos Ficcionistas Brasileiros. Rio de Janeiro: Edições O Cruzeiro, 1958.

ARCO E FLEXA, T. de A. Lúcio Cardoso e Julien Green: Transgressão e culpa. São Paulo, 1990, 377f, (Doutorado em Estudos Literários) Faculdade de Filosofia, Letras e Ciências Humanas, Universidade de São Paulo, São Paulo.

ATHAYDE, T. Nota preliminar. In: PENNA, C. Romances completos. Rio de Janeiro: Nova Aguilar, 1958. p. 3-5.

BARCELLOS, J. C. Literatura e Espiritualidade. Bauru: EDUSC, 2001.

BOSI, A. Lúcio Cardoso. In: História concisa da literatura brasileira. São Paulo: Editora Cultrix, 1978.

BUENO, L. Uma história do romance de 30. São Paulo: Ed. Da Universidade de São Paulo; Campinas: Ed. da Unicamp, 2006.

. Um desbravador original. Folha de S. Paulo, São Paulo, 22 fev 1998. Mais!, p. 6.

Mais!, p. 5.

. A intensidade do pecado. Folha de S. Paulo, São Paulo, 29 dez 1996.

CÂNDIDO, A. A Educação pela Noite. São Paulo: Ática, 1987.

FEDELI, O. Existência de Deus. MONTFORT Associação Cultural. Disponível em: http://www.montfort.org.br/index.php?secao=cadernos\&subsecao=religiao\&arti go=existencia Acesso em: 08/09/2005 às13:44h.

. Maurras. MONTFORT Associação Cultural. Disponível em: http://www. montfort.org.br/index.php?secao $=$ cadernos\&subsecao $=$ religiao\&artigo $=$ maurras 1\&lang=bra Acesso em: 01/10/2005 às10:36h.

GREEN, J. Le voyageur sur la terre. (Le voyageur sur la terre, Les clefs de la Mort, Christine, Léviathan). Paris: Plon, 1997.

- Pamphlet contre les catholiques de france. Paris: Gallimard, 1982.

LAFETÁ, J. L. 1930: a crítica e o modernismo. 2. ed. São Paulo: Duas Cidades, 2000.

MARTINS, W. A crítica literária no Brasil. Rio de Janeiro: Francisco Alves, 1983. 2v.

MILLIET, S. Nota preliminar. In: PENNA, C. Romances completos. Rio de Janeiro: Nova Aguilar, 1958. p. 377-81.

MOURA, O. As idéias católicas no Brasil: direções do pensamento católico do Brasil no século XX. São Paulo: Convívio, 1978.

PENNA, C. Romances completos. Rio de Janeiro: Nova Aguilar, 1958

SILVEIRA, A. Reflexões provocadas por um novo livro de um escritor antigo. Convivium, p. 69-77, jun. 1984. 
TRINDADE, H. Integralismo: o fascismo brasileiro na década de 30. São Paulo: Editora Difel, 1979.

\section{Abstract:}

This work is a brief analysis on the creation of a group of catholic writers both in France and Brazil in the twenties and thirties. Such analysis has two prime objectives: (1) to list some of the recurring themes in the fiction of these writers and (2) to reveal some resemblance which establishes a connection among these novelists, always taking into account the expression of religiosity in their texts. We hope these reflections will permit us to understand the emergence of texts which are so close within different cultures.

\section{Keywords:}

Literature, France, Brazil, novel, religiosity 